\title{
Phytochemical and Biological Screening of Tamarix aphylla L. (Tamaricaceae)
}

\author{
Muhammad Tariq ${ }^{*}$, M Asif Wazir ${ }^{2}$, Waqar Hussain ${ }^{1}$, Shoaib Safadr ${ }^{1}$, Asad Saleem Sial ${ }^{2}$, Khizra Shehzadi ${ }^{1}$ and Adeel \\ Usman $^{2}$ \\ ${ }^{1}$ Department of Pharmaceutical Chemistry, Faculty of Pharmacy, Bahauddin Zakariya University, Multan, Pakistan \\ ${ }^{2}$ Department of Pharmacognosy, Faculty of Pharmacy and Pharmaceutical Sciences, University of Karachi, Karachi, Pakistan \\ *Corresponding Author: Muhammad Tariq, Department of Pharmaceutical Chemistry, Faculty of Pharmacy, Bahauddin Zakariya \\ University, Multan, Pakistan
}

Received: September 10, 2019; Published: September 27, 2019

DOI:_10.31080/ASPS.2019.03.0408

\begin{abstract}
Plants have played fundamental role for development of traditional medicine systems which have been used to cure various diseases for thousands of years in many countries. Tamarix aphylla belongs to family Tamaricaceae commonly known as Faras, Farash and Saltceada, a tree commonly found in Punjab Plains, Sindh, Persia, Mesopotamia, Arabia and South Africa. The present study was aimed to investigate the phytochemical and biological screening of Tamarix aphylla. The investigational plant was collected, authenticated, dried and extraction with two solvents Dichloromethane and methanol was carried out by maceration process. Phytochemical investigation was performed by using standard protocol. Brine shrimp lethality bioassay, insecticidal and anti-inflammatory activity was performed, The result of phytochemical screening shows the presence of alkaloids, tannins, phenols, flavonoids and terpenoids. The stem bark and shoot methanol extract of investigational plant showed significant Brine shrimp lethality activity while insecticidal and anti-inflammatory activities were not present. It was concluded from the present research work that Tamarix aphylla has medicinal and therapeutic significance and positive result in Brine Shrimp lethality may provide a way forward for evaluation of anti-tumor activity but need further investigation.
\end{abstract}

Keywords: Tamarix aphylla; Phytochemical; Brine Shrimp Lethality; Ant-Inflammatory; Anti-Tumor Activity.

\section{Introduction}

In the earliest-initiation of evolution, men have collected a lot of medication information from various kinds of plants. Flora of nature has given us a basic system of antique medicines that has been used by different nations for last centuries. This primary plant system continued in playing necessary role in services of human health. The WHO has estimated that larger part percentage of community depends on conventional methods of treatment for their all types of care (pharmaceutical and medical) of patients (Schultes., et al. 1994). Wounds, sickness, physical inconvenience has restricted the Asian men to use the natural herb for easiness of enduring, torment by the irregular and inappropriate conditions for the prevention against demise and illness. A need for survival of primitive mankind to know about the difference that exist between pharmacological and nutritional herbs. Then information about natural remedies were cascaded to descending or future generations through parent's learning, orally at initiation and later in composed forms like Parchments, Papyi, manuscripts and pharmacopoeia. So, the natural medicinal plants had been utilized in crude forms for the eradication of human.

\section{Literature Review \\ Introduction to Tamarix aphylla (L.) \\ Habitat and distribution}

Tamarix aphylla (L.) is included in our common and large species, this tree is mostly planted on roadside. The galls and bark are utilized for purpose of tanning. It is distributed in Africa (Sudan, Kenya, Libya, Morocoo) Middle East(Israel, Jordan, Saudia Arabia, Yemen, Iran, Kuwait) Pakistan, India and Afghanistan. Tamarix aphylla (L.) can grow in dry and hot zones. In addition to xerophytes and halophytes, it has sandy habitats (Kritikar and Basu, 1933).

\section{Botanical description of tamaricaceae}

Tamaricaceae has four genera and One hundred and twenty species. The plants of Tamaricaceae are sub- tropical, sandy habitat, growing in the maritime and temperate and are cultivated in North Africa, and south- western Africa through central and South Asia. This family has often small trees and bushes. The leaves of Tamaricaceae are like scale and minute and sheathing, sometimes exstipulate and flesh. Flowers are pink or white, regular, bisexual, rearelyunisexular and small, densed racemes, in spikes. There are 
5 or 4 sepals and petals and a minute connate below rarely. There are 4-10 stamens or many, connate or free below and having versatile anthers. The disk is galndular. The ovary is free, mostly one celled or 2-5 celled imperfectly. The styles are free, connate and two to five. On the each 2-5 basal placentas, there are two or many ovules. It has 3-valved capsule. Its seeds are plumed with winged or long hairs crest. It has almost hundred species which are found in subtropical and temperate regions, desert, steppe and shore. The cotyledons and embryo of Tamaricaceae are flat and straight respectively (Kritikar and Basu, 1933).

\section{Botanical description of genus tamarix}

This genus has small trees and shrubs. The leaves are scale like, minute and sheathing or ampilexicaul. The flowers are rosy and white, racemose densely and spicate. The genus Tamarix has four to five free sepals or rearely six. The petals of this genus are below the glandular, crenat angled and lobed disk and at base these petals are connate slightly. Its stamens are five to ten and rearely four or eleven to 12 and inserted at a disk. The ovary of Tamarix is on the apex and is attenuated and having many ovules. The styles of genus are often 3-4 and rarely two to five. The seeds of this genus are small and glabrous, generated on the apex in a plume(sessile), The axis is feathered having longer hairs, setiform. The embryo of Tamarix is oblong and ovoid. The species of this genus are 65 in number and these are distributed in diverse regions like European and Asian countries. Many species of this genus have used in traditional system of medicine. Some species of Tamarix are used for treating the disorders of liver. Some other are used for purpose of diaphoresis and diuresis. Some are used to treat the various types of headaches (Kritikar and Basu, 1933).

\section{Taxonomy of Tamarix aphylla (L.)}

Taxonomy of Tamarix aphylla (L.) is given below (Drabu., et al. 2012)

\section{Kingdom: Plantae}

Subkingdom: Tracheobionta

Division: Magnoliophyta

Class: Magnoliopsida

Order: Violales

Family: Tamaricaceae

Genus: Tamarix

Species: Aphylla

\section{Botanical characteristics of Tamarix aphylla (L.)}

Tamarix aphylla (L.) is small tree or a shrub, having branches like pendulous and with slender erection. The leaves of Tamarix aphylla (L.) are 2 to $4 \mathrm{~mm}$ long, in first, imbricate and distant afterwards, amplexicaul, subulate-acute. Flowers of Tamarix aphylla (L.) are numerous, crowded and hermaphrodite, in slender laterlally, recemes are like spike. Pedicles are short and having acute bracts, below the flowers immediately. There are sepals five in number and these are smaller than petals, ovate and triangular, margins are denticulate minutely. There are oblong petals. Stamens are 5 and put at the margin of middle disk lobes. Its ovary is trigonous, bottle-shape, at top truncate. The capsules are conical, almost $4 \mathrm{~mm}$ long, trigonous, glabrous, pink, pale and tapering. Seeds of Tamarix aphylla (L.) have white hairs in plume. Its bark is tonic, astringent and bitter. The leaves and fruits are bitter slightly and sour (Kritikar and Basu, 1933).

\section{Materials and Methods}

Phytochemical screening and analysis of biological activities of bark stem and shoots of Tamarix aphylla (L.) was done in pharmaceutical chemistry research lab, Department of Pharmacy BZU Multan. The detailed description of chemicals, instrumentation, and methods involved in this process of research is descripted as following.

\section{Collection and identification of plant}

The stem bark and shoots of Tamarix aphylla (L.) were gathered from Bio Park BZU Multan under the supervision of Prof. Dr. Muhammad Uzair (Chairman of Department of Pharmaceutical chemistry, BZU Multan). The plant was brought to the Department of Biology to get identification. Plant was discerned as Tamarix aphylla (L.) by Associate Professor Dr. Zafar-Ullah- Zafar and voucher Number. "RR Stewart F. W. Pak 489(4) was subjected.

\section{Drying of Tamarix aphylla (L.)}

The stem bark and shoots were collected and cut into smaller pieces disparately. Then these smaller pieces of stem bark and shoots were put into shade for 40- 45 days for appropriate drying. The dried pieces were squashed and powder was got in suitable form for extraction.

\section{Extraction of Tamarix aphylla (L.)}

800 grams of powder of stem bark was distributed into two equal parts and put into bottles of glass. Then powder of these two glass bottles were macerated in methanol and dichloromethane separately. This socked powder of both glass bottles was agitated at particular time intervals to acquire maximum extraction. $800 \mathrm{~g}$ powder of shoots was subjected to extraction with same solvents used in stem bark powder of the plant. First filtration was done after 3 days and $2^{\text {nd }}$ filtration was done after 4 days. Then extra methanol and dichloromethane were evaporated by using rotary evaporator Finally methanol stem bark extract, DCM methanol extract and methanol shoot extract and DCM shoot extract were collected in two small glass jars for more drying. These extracts were named as TABM, TASM, TABD and TASD.

\section{Phytochemical screening}

To assure the availability of various secondary metabolites in methanolic extracts of stem bark and shoot of Tamarix aphylla (L.) tests having standard methods were performed, these are given below (Raaman, 2008). 


\section{Alkaloids screening tests}

- Mayer's Reagent test: About 0.5 to $1 \mathrm{ml}$ of reagent was added to small amount of extract solution, alkaloids were confirmed.

- Wagner's Reagent Test: Methanol and DCM extracts having volume 2 to $3 \mathrm{ml}$ were mixed with 4 to 5 drops of this reagent and presence of alkaloids were confirmed by brown color precipitates.

- Hager's Reagent test: Solution of Plant extract having volume about $2 \mathrm{ml}$ mixed with $5 \mathrm{ml}$ of reagent. Pale yellowish color precipitates confirm the presence of alkaloids.

- Dragandorff, s Reagent Test: Two milliliter extract solution was taken in test tube and 3-5 drops of reagent was mixed. Pink colour or light red colour precipitate confirmed the alkaloids.

- Tannic acid Test: Buff coloured precipitation was appeared on mixing of tannic acid 4-5 drops Tannic acid confirmed the alkaloid presence.

Test for terpenoids

$3 \mathrm{ml}$ of extract solution was mixed with small volume of chloroform then Concentrated Sulphuric acid was added as a result layer was developed a brown colour of layer confirm the terpenoidspresence.

\section{Quinone test}

Extract solution having a volume $3 \mathrm{ml}$ was treated with small amount of sodium hydroxide greenish blue or red colour confirm the quinone presence.

\section{Test of flavonoids}

- NaOH Test: Sodium hydroxide solution was diluted and added to the extract solution in a test tube and then concentrated $\mathrm{HCl}$ was added orange colour confirm the flavonoid presence.

- $\quad \mathbf{H}_{2} \mathbf{S O}_{4}$ Test: Plant extract solution with 2-4 ml volume was mixed with $1 \mathrm{ml}$ sulphuric acid, flavonoids presence was confirmed by orange colour appearance.

- Lead acetate Test: Extract solution having a volume 4-5 ml in a small test tube was mixed with lead acetate flavonoid presence was confirmed by cream colour precipitate.

Test for phenol

- Ferric Chloride test: Few ml of plant extract solution was treated with ferric chloride solution dark blue colour confirm the phenol presence.

Test for tannins

$\mathrm{FeCl}_{3}$ with a volume of $1 \mathrm{ml}$ was combined with $2 \mathrm{ml}$ of plant extract solution. Black coloured confirmed the presence of tannins.
Test for saponin

Distilled water having a volume of 2-3 ml was mixed with 2-4 $\mathrm{ml}$ of extract solution persistent froth formation upon shaking confirm the saponin presence.

Test for protein

- Xanthoproteic Test: $2-3 \mathrm{ml}$ of concentrated nitric acid was mixed with 2-4 ml of plant extract solution. Pale colour confirms the protein presence.

- Anthraquinone Test: Potassium hydroxide with 5-6 drops were mixed with plant extract solution having volume 2-4 $\mathrm{ml}$ blood red colour gives the confirmation of anthraquinone presence.

Chromatographic techniques

Thin layer chromatography

- Quick and reliable analytical

- Low cost and simple technique

- Wider range of choice for use of mobile phase

- Analytical process leading to preparative separation.

This analytical technique is used to separate the different constituents of non-volatile nature present in a mixture and constituents are separated with the help of capillary action of mobile phase over stationary phase.

\section{Procedure}

TLC sample solution was made by dissolving $20 \mathrm{mg}$ of (TABM and TASM) in $20 \mathrm{ml}$ methanol and dissolve $20 \mathrm{mg}$ of (TABD and TASD) in $20 \mathrm{ml}$ dichloromethane. The sonication of prepared solutions was done and then filtration was carried out to dissolve the suspended particles of plant extract, 3-5 drops of specific solvents were added. The bottom side of TLC plate was considered and bottom line on TLC plate was drawn, then solvent front line above $1.5 \mathrm{~cm}$ to $2 \mathrm{~cm}$ on vertical edge was drawn. TLC sample spots were fixed at bottom line and specified these spots with names of BM, SM and BD, SD. Various combinations of mobile phases were made in different vessels for different prepared plant extract TLC samples. Then different mixtures of mobile phases having volume $20 \mathrm{ml}$ were taken into TLC tank. Inside environment of TLC tank was simulated and saturated by closing the tank with lid of TLC tank and kept the TLC tank on smooth surface for 10 to 15 minutes. In the same time, spots of the sample were applied on the line above bottom of plate by using small capillary tube. In the saturated environment by the mixture solutions of mobile phase, TLC plates having dried spots of different samples were placed. That were dipped in solution and supported by tank wall. Moving on the TLC plate when mobile phase came over line of solvent front, plate was picked out and dried by feasible technique to observe under UV illuminator of visible range at two particular wavelengths (254 nanometer and 366 nanometer). Circles of continuous line ( 
and discontinuous line (- - - -) were used to locate the spots visible at 254 nanometer and 366 nanometers respectively. Then drying was done at $110^{\circ} \mathrm{C}$ to $115^{\circ} \mathrm{C}$ in oven for 2 to 3 minutes. Location of colored separation was identified by $(/ / / / / / / / / / /)$ lines.

The $\mathrm{R}_{\mathrm{f}}$ values was calculated by its formulae.

The ratio of distance travelled by component to travelled distance by solvent front is descripted as $\mathrm{R}_{\mathrm{f}}$ value.

\begin{tabular}{|l|c|c|}
\hline \multicolumn{1}{|c|}{ Methanol Extract } & Methanol extract & DCM extract \\
\hline $\begin{array}{l}\text { Chloroform: } \\
\text { methanol: water }\end{array}$ & $\begin{array}{c}\text { Ethyl acetate: } \\
\text { methanol }\end{array}$ & $\begin{array}{c}\text { n-Hexane: Ethyl } \\
\text { acetate }\end{array}$ \\
\hline $70: 3: 4$ & $77: 13: 10$ & $50: 50$ \\
\hline $85: 15: 1$ & $85: 15: 5$ & $60: 40$ \\
\hline $90: 10: 5$ & $90: 10: 5$ & $70: 30$ \\
\hline
\end{tabular}

Table 1: Mobile phases used in TLC analysis of methanol extracts and DCM of stem bark and shoot of Tamari x aphylla (L.).

\section{Column chromatography}

It is an analytical technique which based upon adsorption principle, in which separation and purification of mixture constituents is carried out. Mobile phase in combination is passed through stationary phase packed in column of tube shape. In first step, column rinsing is done with distilled $\mathrm{H}_{2} \mathrm{O}$ and column in dry state is fixed vertically with particular stand. After this Cotton plug is fastened securely in inside of column and this is packed slurry of stationary phase that is made by combining and mixing the mobile with silica placed in conical flask having volume of $1 \mathrm{~L}$. The stationary phase was settled down in the bottom side. Plant extract sample solutions were made in respective mobile phase system. The sample was applied with the use of funnel at opening of column. The $3 \mathrm{ml} /$ minute was flowing rate for elution. To prevent cracking of development and for effective analysis line of solvent was not permitted to run below mark level of adsorbent and solvent layer is not disturbed during the filling with mobile phase. Elution was kept up until each component collection having the volume of thirty milliliter $(30 \mathrm{ml})$.

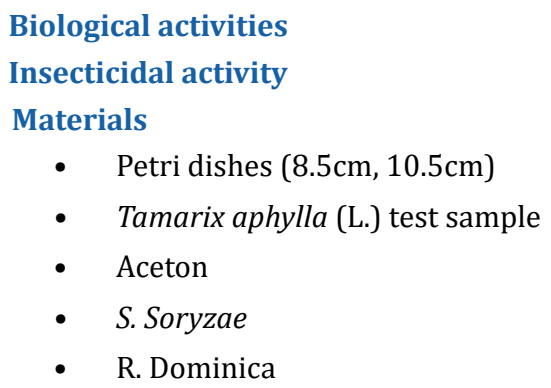

Procedure

Following steps are involved in procedure

- In aceton, Plant extract dilution was made.

- Took the insects for test

- aceton- extract dilution was taken into petridish.
- For 5-10 min, solution is kept.

- In the sample Petri dishes and controlled, insects for tests were taken.

- At interval of one day, for three times procedure was repeated.

- $\%$ age mortality determination was carried out.

\section{Brine shrimp lethality bioassay}

Biologically active constituents are frequently toxic to the leach of Artemia salina larvae. Brine Shrimp Artemia salina eggs are easily present in pet shops as a food of fish. When these eggs are placed artificially in seawater after hatching in 48 hours provides number of larvae. This method was developed for fractionation, monitoring and screening of biologically active natural products. This method is cheap, commonly used rapid general bioassay.

\section{Material and Method}

Artemia salina test sample (shrimp's eggs) sea salt (37 gm/L of distilled $\mathrm{H} 2 \mathrm{O}$ with PH 7.4) hatching tray having perforated partition, Brine shrimp larvae is attracted by using the lamp. Micropipette of different volume like (5, 50 and 500 microliter) is used. Vial tray containing 9 vials of organic solvents such as methanol/ ethanol, aceton/water.

\section{Eggs storage of Artemia salina}

For the storage of Artemia salina eggs, $4^{\circ} \mathrm{C}$ is required temperature. They remain viable at this temperature for many years.

\section{Techniques of hatching}

Hatching tray such as rectangular dish with diameter $(22 \times 32$ $\mathrm{cm}$ ) is half filled having filtered brine solution. Brine shrimp eggs are sprinkled after filling at the temperature of $37^{\circ} \mathrm{Cis}$ requirement for incubation.

\section{Preparation of sample}

$20 \mathrm{mg}$ of test sample is dissolved in $2 \mathrm{ml}$ of respective solvent. Transfer the sample solution in in the vials having volume of 5, 50 and $500 \mu \mathrm{m}$. The concentration of vials 10,100 and $1000 \mu \mathrm{m}$. Keep the sample for overnight to evaporate the solvent. After hatching and maturation of nauplii, placed 10 larvae in each vial by using the Pasture pipette after two days. Final volume of $5 \mathrm{ml}$ makes with seawater. Incubate for 1 day at $25-27^{\circ} \mathrm{C}$ under light. Cytotoxic drug used for positive and negative control respectively. Finney computer programmed used to analyze the data, For the determination of LD50 values with $95 \%$ confidence intervals. After the start of hatching Shrimps can be used after 2-3 days. Shrimp should be discarded after 3 days (Alves., et al. 2000).

\section{Anti-inflammatory activity}

Anti-inflammatory activity was performed by luminol enhanced chemiluminescence, as described by (Helfand., et al. 1982). Hanks balanced salt soln. of whole blood containing calcium chloride and Magnesium chloride of $25 \mu$ incubated with $25 \mu$ of 3 different 
concentration of compounds such as 1,10 , and $100 \mu \mathrm{g} / \mathrm{ml}$, every concentration in triplicate form. HBSS++ and cells, but no compounds are placed in controlled vials. To perform the test white half area nighty six well plates are used, that is incubated at $37 \pm$ $1^{\circ} \mathrm{C}$. in the thermostat chamber of luminometer for $15 \mathrm{~m} .25 \mu \mathrm{l}$ of serum opsonized zymosan and 25 microliter of intracellular reactive oxygen species detecting probe, luminol after incubation are added into every well except blank well which containing only Hanks balanced salt solution. In Luminometer, ROS level is recorded in terms of relative light unit. Ibuprofen is used as standard drug for the assay having $\mathrm{IC}_{50}=11.2 \pm 1.9$.

\section{Anti-bacterial method}

96 Well Plate method

- Mueller Hinteon medium was used to grow microorganism

- Dimethyl sulfoxide (1:1) was used to prepare stock solution of different test compounds

- The media was dispensed in all the wells.

- The whole work was performed in triplicate form.

- $\quad$ All the reagents were added in the well but in controlled wells any test reagents were not added

- Final volume, up to $200 \mu \mathrm{l}$ of 96 well plate was made

- Cells were added in the control and test wells respectively.

- All the plates were sealed with parafilm were incubated for 17- 20 hours.

- In all the wells, Alamar blue dyes was added and all the plates were shaken in a shaking incubator at the specific frequency having 80 rounds per minute for 120 to 180 minutes

- Growth in bacterial strains were indicated by the change in color from blue to pink of Alamar blue dye.

- Enzyme linked immunosorbent assay (ELIZA) reader was used to record the absorbance at $570 \mathrm{~nm}$ and $600 \mathrm{~nm}$ (Pettit., et al. 2005).

Extraction of stem bark and shoot of Tamarix aphylla (L.)

Extraction of Stem Bark and shoot of Tamarix aphylla (L.) was done by the maceration process successively by using two different organic solvents dichloromethane and methanol. The results of extraction are shown in the table 2 and table 3.

\section{Result of Biological activities}

\section{Insecticidal activity}

The results of insecticidal action of dichloromethane and methanol extracts from stem and shoot of Tamarix aphylla(L.) are given below in the tables.

\begin{tabular}{|c|c|c|c|c|}
\hline Sr No & Tests & Reagents & Stem Bark & Shoot \\
\hline \multirow[t]{4}{*}{1} & \multirow[t]{4}{*}{ Alkaloids } & Dragandorff, s & + & + \\
\hline & & Wagner & + & + \\
\hline & & Mayer & + & + \\
\hline & & Hager & + & + \\
\hline 2 & Anthraquinone & $\mathrm{CuSO}_{4}$ & - & + \\
\hline 3 & Protein & $\begin{array}{c}\text { Xanthoprotic } \\
\text { test }\end{array}$ & + & + \\
\hline \multirow[t]{3}{*}{4} & \multirow[t]{3}{*}{ Tannins } & Lead acetate & + & + \\
\hline & & $\mathrm{FeCl}_{3}$ & + & + \\
\hline & & Gelatin & + & + \\
\hline \multirow[t]{3}{*}{5} & \multirow[t]{3}{*}{ Flavonoids } & Lead acetate & + & + \\
\hline & & $\mathrm{FeCl}_{3}$ & + & + \\
\hline & & $\mathrm{NaOH}$ & + & + \\
\hline 6 & Phenols & $\mathrm{FeCl}_{3}$ & + & + \\
\hline 7 & Terpenoids & Chloroform test & + & + \\
\hline 8 & Quinones & $\mathrm{KOH}$ & - & - \\
\hline 9 & Saponins & Dist. Water & + & + \\
\hline
\end{tabular}

Table 2: Phytochemical analysis of Tamarix aphylla.

\begin{tabular}{|c|c|c|c|c|c|}
\hline \multirow{2}{*}{$\begin{array}{l}\text { Sr. } \\
\text { no }\end{array}$} & \multirow{2}{*}{$\begin{array}{l}\text { Powdered } \\
\text { drug }\end{array}$} & \multicolumn{2}{|c|}{ Visible/daylight } & \multicolumn{2}{|c|}{ UV Light } \\
\hline & & Stem bark & Shoot & $\begin{array}{l}\text { Stem } \\
\text { bark }\end{array}$ & Shoot \\
\hline 1 & $\begin{array}{c}\text { Powder + } \\
\text { water }\end{array}$ & Brown & $\begin{array}{c}\text { Light } \\
\text { brown }\end{array}$ & White & Turquoise \\
\hline 2 & $\begin{array}{c}\text { Powder+ } \\
\text { Conc.HNO }_{3}\end{array}$ & $\begin{array}{l}\text { Light or- } \\
\text { ange }\end{array}$ & Orange & $\begin{array}{c}\text { Blackish } \\
\text { brown }\end{array}$ & Brown \\
\hline 3 & $\begin{array}{c}\text { Powder+ } \\
\text { Chloroform }\end{array}$ & $\begin{array}{l}\text { Light } \\
\text { Brown }\end{array}$ & $\begin{array}{c}\text { Light } \\
\text { brown }\end{array}$ & $\begin{array}{c}\text { Light } \\
\text { brown }\end{array}$ & White \\
\hline 4 & $\begin{array}{c}\text { Powder+ } \\
\text { Acetic acid }\end{array}$ & Brown & $\begin{array}{c}\text { Light } \\
\text { brown }\end{array}$ & $\begin{array}{l}\text { Light } \\
\text { green }\end{array}$ & Turquoise \\
\hline 5 & $\begin{array}{c}\text { Powder+ } \\
\text { Conc. } \mathrm{H}_{2} \mathrm{SO}_{4}\end{array}$ & Black & Green & $\begin{array}{l}\text { Light } \\
\text { green }\end{array}$ & Green \\
\hline 6 & $\begin{array}{l}\text { Powder+ } \\
\text { Methanol }\end{array}$ & Brown & $\begin{array}{l}\text { Light } \\
\text { green }\end{array}$ & White & white \\
\hline 7 & $\begin{array}{l}\text { Powder+ } \\
\text { Iodine }\end{array}$ & $\begin{array}{l}\text { Light } \\
\text { brown }\end{array}$ & $\begin{array}{c}\text { Light } \\
\text { brown }\end{array}$ & $\begin{array}{l}\text { Light } \\
\text { green }\end{array}$ & Turquoise \\
\hline 8 & $\begin{array}{l}\text { Powder+ } \\
\text { Glycerin }\end{array}$ & Brown & $\begin{array}{c}\text { Light } \\
\text { brown }\end{array}$ & $\begin{array}{l}\text { White } \\
\text { green }\end{array}$ & Turquoise \\
\hline 9 & $\begin{array}{c}\text { Powder + } \\
5 \% \mathrm{FeCl}_{3}\end{array}$ & $\begin{array}{c}\text { Yellowish } \\
\text { green }\end{array}$ & $\begin{array}{l}\text { Blood } \\
\text { red }\end{array}$ & $\begin{array}{c}\text { Blackish } \\
\text { green }\end{array}$ & Black \\
\hline 10 & $\begin{array}{l}\text { Powder }+ \\
1 \% \mathrm{NaOH}\end{array}$ & $\begin{array}{c}\text { Dark } \\
\text { brown }\end{array}$ & Brown & $\begin{array}{l}\text { Light } \\
\text { Cream }\end{array}$ & Light green \\
\hline 11 & $\begin{array}{c}\text { Powder } \\
+ \text { Glacial } \\
\text { acetic acid }\end{array}$ & $\begin{array}{l}\text { Light } \\
\text { brown }\end{array}$ & $\begin{array}{c}\text { Light } \\
\text { brown }\end{array}$ & Cream & Turquoise \\
\hline 12 & $\begin{array}{l}\text { Powder }+ \\
\text { Picric acid }\end{array}$ & Brown & Yellow & Brown & Brown \\
\hline 13 & $\begin{array}{c}\text { Powder + } \\
\mathrm{NH}_{4} \mathrm{OH}\end{array}$ & Brown & $\begin{array}{c}\text { Dark } \\
\text { brown }\end{array}$ & $\begin{array}{c}\text { Tur- } \\
\text { quoise }\end{array}$ & White \\
\hline 14 & $\begin{array}{c}\text { Powder + } \\
\text { aceto nitryl }\end{array}$ & $\begin{array}{l}\text { Mud } \\
\text { Brown }\end{array}$ & White & White & light pink \\
\hline 15 & $\begin{array}{l}\text { Powder } \\
\text { + Diethyl } \\
\text { ether }\end{array}$ & $\begin{array}{l}\text { Light } \\
\text { brown }\end{array}$ & $\begin{array}{c}\text { Light } \\
\text { brown }\end{array}$ & White & Turquoise \\
\hline
\end{tabular}

Table 3: Fluorescence analysis of Tamarix aphylla of stem bark and shoot. 


\begin{tabular}{|l|c|c|c|}
\hline \multirow{2}{*}{ Name of Insects } & \multicolumn{2}{|c|}{$\%$} & \multirow{2}{*}{ Sample } \\
\cline { 2 - 4 } & +Ve Control & -Ve Control & \\
\hline Tribolium castaneum & -- & -- & - \\
\hline Sitophilus oryzae & $100 \%$ & $0 \%$ & $0 \%$ \\
\hline Rhyzoperthado minica & $100 \%$ & $0 \%$ & $0 \%$ \\
\hline Callossbruchu sanalis & - & - & - \\
\hline $\begin{array}{l}\text { Trogoderma } \\
\text { granarium }\end{array}$ & - & - & - \\
\hline
\end{tabular}

Table 4: Insecticidal activity of Tamarix aphylla (L.) stem bark methanol.

Conc. of Sample $=1019.10 \mu \mathrm{g} / \mathrm{cm}^{2}$; Conc. of Standard $=239.5 \mu \mathrm{g} /$ $\mathrm{cm}^{2} ;$ Standard Drug $=$ Permethrin

\begin{tabular}{|l|c|c|c|}
\hline \multirow{2}{*}{\multicolumn{1}{|c|}{ Insects }} & \multicolumn{2}{|c|}{$\%$ Mortality } & \multirow{2}{*}{ Sample } \\
\cline { 2 - 4 } & +Ve Control & -Ve Control & \\
\hline Tribolium castaneum & - & - & - \\
\hline $\begin{array}{l}\text { Rhyzoperthado } \\
\text { minica }\end{array}$ & $100 \%$ & $0 \%$ & $0 \%$ \\
\hline Sitophilus oryzae & $100 \%$ & $0 \%$ & $0 \%$ \\
\hline Callossbruchu sanalis & - & - & - \\
\hline $\begin{array}{l}\text { Trogoderma } \\
\text { granarium }\end{array}$ & - & - & - \\
\hline
\end{tabular}

Table 5: Insecticidal activity of Tamarix aphylla (L.) shoot methanol.

Conc. of Sample $=1019.10 \mu \mathrm{g} / \mathrm{cm}^{2}$; Conc. of Standard $=239.5 \mu \mathrm{g} /$ $\mathrm{cm}^{2} ;$ Standard Drug $=$ Permethrin.

\begin{tabular}{|c|c|c|c|c|c|}
\hline $\begin{array}{c}\text { Dose } \\
\mu \mathrm{g} / \mathrm{m} \mid\end{array}$ & $\begin{array}{c}\text { No. of } \\
\text { Shrimps } \\
\end{array}$ & $\begin{array}{c}\text { No. of } \\
\text { Survivors } \\
\end{array}$ & Mortality & $\begin{array}{c}\text { Standard } \\
\text { drug }\end{array}$ & $\begin{array}{c}L_{D_{50}} \\
\mu \mathrm{g} / \mathrm{ml}\end{array}$ \\
\hline 10 & 30 & 24 & $20 \%$ & \multirow[t]{3}{*}{ Etoposide } & \multirow[t]{3}{*}{$46.66 \%$} \\
\hline 100 & 30 & 19 & $36.66 \%$ & & \\
\hline 1000 & 30 & 16 & $46.66 \%$ & & \\
\hline
\end{tabular}

Table 6: Results of Brine Shrimp Lethality Bioassay of shoot methanolic extract of Tamarix aphylla (L.).

\begin{tabular}{|c|c|c|c|c|c|}
\hline $\begin{array}{c}\text { Dose } \\
\mu \mathrm{g} / \mathrm{ml}\end{array}$ & $\begin{array}{c}\text { No. of } \\
\text { Shrimps }\end{array}$ & $\begin{array}{c}\text { No. of } \\
\text { Survivors }\end{array}$ & Mortality & $\begin{array}{c}\text { Standard } \\
\text { drug }\end{array}$ & $\begin{array}{c}\mathrm{LD}_{50} \\
\mu \mathrm{g} / \mathrm{ml}\end{array}$ \\
\hline 10 & 30 & 23 & $23.33 \%$ & \multirow{3}{*}{ Etoposide } & \multirow{3}{*}{$46.66 \%$} \\
\hline 100 & 30 & 23 & $23.33 \%$ & & \\
\hline 1000 & 30 & 18 & $40 \%$ & & \\
\hline
\end{tabular}

Table 7: Results of Brine Shrimp Lethality Bioassay of stem bark methanolic extract of Tamarix aphylla (L.).

\begin{tabular}{|c|c|c|c|}
\hline $\begin{array}{c}\text { Conc. } \boldsymbol{\mu g} / \\
\text { ml }\end{array}$ & $\begin{array}{c}\text { \% inhibition/ } \\
\text { Stimulation }\end{array}$ & $\begin{array}{c}\text { Standard } \\
\text { Drug }\end{array}$ & $\begin{array}{c}\text { \% inhibition/ } \\
\text { Stimulation } \\
\text { Standard Drug }\end{array}$ \\
\hline $25 \mu \mathrm{g} / \mathrm{ml}$ & $39.4 \%$ & Ibuprofen & $73.2 \%$ \\
\hline
\end{tabular}

Table 8: Results of Anti-inflammatory activity of Tamarix aphylla (L.) shoot methanol

\begin{tabular}{|c|c|c|c|}
\hline $\begin{array}{c}\text { Conc. } \mu \mathrm{g} / \\
\mathbf{m l}\end{array}$ & $\begin{array}{c}\text { \% inhibition/ } \\
\text { Stimulation }\end{array}$ & $\begin{array}{c}\text { Standard } \\
\text { Drug }\end{array}$ & $\begin{array}{c}\text { \% inhibition/ } \\
\text { Stimulation } \\
\text { Standard Drug }\end{array}$ \\
\hline $25 \mu \mathrm{g} / \mathrm{ml}$ & $33.4 \%$ & Ibuprofen & $73.2 \%$ \\
\hline
\end{tabular}

Table 9: Results of Anti-inflammatory activity of Tamarix aphylla (L.) stem bark methanol.

Thin layer chromatography of shoot and stem extracts of Tamarix aphylla

TLC analysis of dichloromethan and methanol extracts of Tamarix aphylla was carried with different solvent systems i.e. chloroform: methanol: water system for methanolic extracts, n-hexane: ethyl acetate and n-hexane: IPA mixtures were used for DCM extracts It is shown in figure.

Analysis of methanol extracts of stem bark and shoot were done on thin layer chromatography and Rf values of active components were determined. TABM extract with mobile phase (85:15:1) was resolved into 10 components were identified after spraying the locating agents, having Rf values; 0.17, 0.33, 0.42, 0.50, 0.62, 0.74, $0.80,0.84,0.90,0.93$. and TASM extract was resolved on TLC into 11 active components having Rf values; $0.12,0.20,0.26,0.40,0.49$, $0.58,0.68,0.74,0.80,0.86,0.93$. Then mobile phase was changed with (90:10: 0.5$)$, TABM extract was resolved into 8 components on TLC plate having Rf values; $0.12,0.27,0.33,0.44,0.54,0.74$, $0.90,0.95$ and TASM extract was resolved into 7 components were detected in the same mobile phase system with values; $0.20,0.28$, $0.37,0.48,0.63,0.87,0.94$. The analysis of DCM extracts of stem bark and shoot were done on TLC plate and components Rf value was calculated. The stem bark DCM extract (B.D) and shoot DCM extract (S.D) in mobile phase of n-hexane: ethyl acetate (50: 50) was resolved to 6, 6 active components respectively having $\mathrm{Rf}$ values; $0.67,0.74,0.78,0.83,0.90,0.94$ and $0.41,0.72,0.79,0.87$, $0.93,0.97$. Then TLC results of DCM extract of stem bark and shoot were taken with changed ratio of n-Hexane: Ethyl acetate (70: 30) with identification of 7,7 components respectively having $\mathrm{Rf}$ values; $0.18,0.61,0.67,0.85,0.88,0.90,0.96$ and $0.09,0.38,0.66,0.76$, $0.83,0.88,0.90$. 


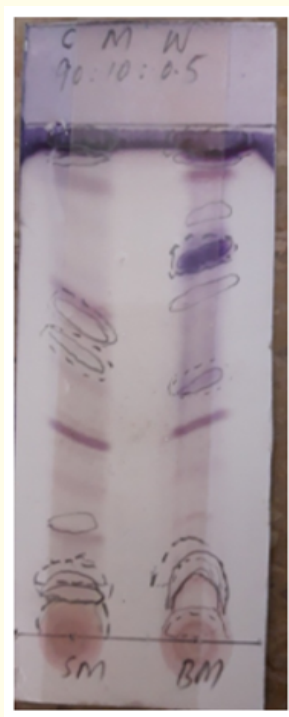

(A)

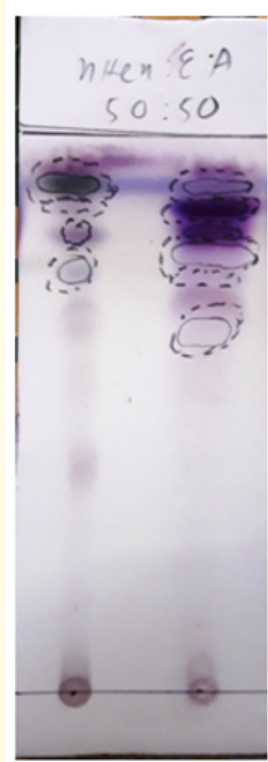

(C)

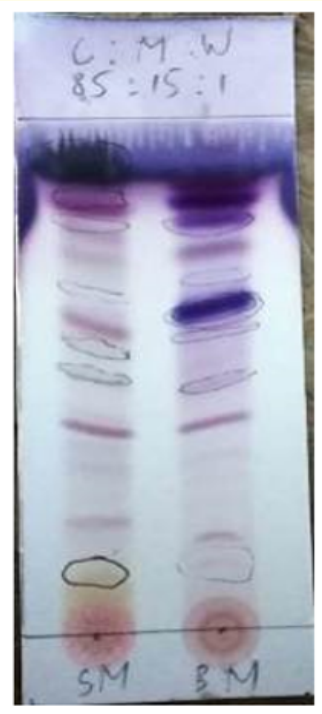

(B)

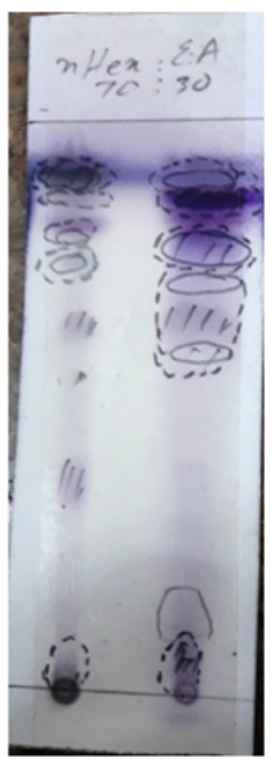

(D)

\section{Figure}

\section{Discussion and Conclusion}

The screening of secondary metabolites and pharmacological activities of Tamarix aphylla (L.) (Stem bark and shoot) was done to explore the its medicinal importance. Preliminary screening of secondary metabolites revealed the presence of flavonoids, sterols, terpenoids, alkaloids, tannins, in the methanolic extract of stem bark of Tamarix aphylla (L.). The presence of secondary metabolites is responsible for its different pharmacological activities [117].

The brine shrimp Artemia Salina is a test, used to determine the cytotoxic effect of different bioactive compounds. Methanol extract of Tamarix aphylla (L.) stem bark showed moderate activity at lower concentration while significant activity at highest concentration, similarly methanolic extract of shoot of Tamarix aphylla (L.) showed significant activity at higher concentration. Etoposide was used as standard drug.

Insecticidal activity of methanolic extract of stem bark and shoot of Tamarix aphylla (L.) was investigated by contact toxicity method but sample showed no significant activity at low, moderate and also at higher concentration. Standard drug was Permethrin.

Similarly, Anti-inflammatory activity of methanolic extract of stem bark and shoot was investigated by Luminol-enhanced chemiluminescence assay was performed and extract showed no activity at low, moderate and higher concentration. The Standard drug was Ibuprofen.

Chromatographic analysis such as column chromatography and Thin layer chromatography of methanol extract of Tamarix aphylla (L.) showed the presence of numerous biologically active compounds of different nature by using different advanced analytical techniques such as FTIR, Novel compounds can be identified which can be used as a significant therapeutic agent.

\section{Bibliography}

1. Alrumman SA. "Phytochemical and Antimicrobial Properties of Tamarix aphylla L. Leaves Growing Naturally in the Abha Region, Saudi Arabia". Arabian Journal for Science and Engineering 41 (2016): 2123-2129.

2. Bakr RO., et al. "Phenolic content, radical scavenging activity and cytotoxicity of Tamarixnilotica (Ehrenb.) bunge growing in Egypt". Journal of Pharmacognosy and Phytotherapy 5 (2013): 47-52.

3. Bol D and Ebner R. "Gene expression profiling in the discovery, optimization and development of novel drugs: one universal screening platform". Pharmacogenomics 7 (2006): 227-235.

4. Bull AT and Stach JE. "Marine actinobacteria: new opportunities for natural product search and discovery". Trends Microbiology 15 (2007): 491-499.

5. Butler MS. "Natural products to drugs: natural product-derived compounds in clinical trials". Natural Product Reports 25 (2008): 475-516.

6. Charlish P. "Traditional remedies: latter day medicines". Scrip World Pharmaceutical News 3351 (2008): 31-34.

7. Chemler JA., et al. "Combinatorial mutasynthesis of flavonoid analogues from acrylic acids in microorganisms". Organic Letters 9 (2007): 1855-1858.

8. Chin YW., et al. "Drug discovery from natural sources". AAPS 8 (2006): E239-E253. 
9. Do QY., et al. "Reverse pharmacognosy: identifying biological properties for plants by means of their molecule constituents: application to meranzin". Planta Medica 73 (2007): 12351240 .

10. Domenjoz R., et al. "The Effect of Anti-inflammatory Agents on Formalin Edema and On The Vitamin Cand Cholesterol Content of The Adrenal Glands in Hypophysectomized Rats". Archives Internationales de Pharmacodynamie et de Therapie 103 (1995): 341-352.

11. Ehrman TM., et al. "Phytochemical informatics of traditional Chinese medicine and therapeutic relevance". Journal of Chemical Information and Modeling 47 (2007): 2316-2334.

12. Feher M and Schmidt JM. "Property distributions: differences between drugs, natural products, and molecules from combinatorial chemistry". Journal of chemical information and computer sciences 43 (2003): 218-227.

13. Galm U and Shen B. "Natural product drug discovery: the times have never been better". Chemistry and Biology 14 (2007): 1098-1104.

14. Ghazanfar S. "Handbook of Arabian medicinal plants". CRC Press Inc., United State of America (1994).

15. Harvey AL. "Strategies for discovering drugs from previously unexplored natural products". Drug Discovery Today 5 (2000): 294-300.

16. Harvey AL. "Natural Product Pharmaceuticals: A Diverse Approach to Drug Discovery, Scrip Reports". PJB Publications (2001).

17. Jacob S and Bsvski M. Arch. Inter. Pharamacody. In: Ramadan A, Harraz FM, eL-Mougy SA. Anti-inflammatory, Analgesic and Antipyretic Effects of The Fruit Pulp of Adansoniadigitata. Fitoterapia. 65 (1994): 418-422.

Volume 3 Issue 10 October 2019

(C) All rights are reserved by Muhammad Tariq., et al. 